\title{
Activation of second messenger pathways in alveolar macrophages by endotoxin
}

\author{
M.M. Monick, G.W. Hunninghake
}

\begin{abstract}
Activation of second messenger pathways in alveolar macrophages by endotoxin. M. M. Monick, G.W. Hunninghake. C) ERS Journals Ltd 2002.

ABSTRACT: The alveolar macrophage plays an important role in immune surveillance of the lung. Early responses to infectious agents by macrophages can decrease tissue injury and promote recovery of the host. Macrophage responses to pathogens are the cornerstone of the innate or nonspecific immune system. In particular, the response of macrophages to endotoxin from Gram negative bacteria has been the focus of many recent studies. The recent discovery of the endotoxin receptor has accelerated the study of signalling in macrophages. This review focuses on the downstream events that occur following exposure of the alveolar macrophage to endotoxin. Eur Respir J 2002; 20: 210-222.
\end{abstract}

Dept of Medicine, University of Iowa College of Medicine and Veterans Administration Medical Centre, Iowa City, IA, USA.

Correspondence: M.M. Monick, Division of Pulmonary, Critical Care and Occupational Medicine, Room 100, EMRB, The University of Iowa Hospitals and Clinic, Iowa City, IA 52242, USA.

Fax: 13193356530

E-mail: martha-monick@uiowa.edu

Keywords: Endotoxin, macrophage, mitogen-activated protein kinase, nuclear factor- $\kappa \mathrm{B}$, phosphatidylinositol 3-kinase, sphingolipids

Received: January 162002

Accepted after revision: March 52002
Macrophages are the major effector cells of the innate immune system (fig. 1). The term macrophage" was first used more than 100 yrs ago by Elie Metchnikoff to describe large mononuclear phagocytes seen in tissues [1]. Macrophages are highly distributed throughout the body in the lymphoid organs, liver, lung, gastrointestinal tract, central nervous system, serous cavities, bone, synovium and skin. They originate in the bone marrow as monoblasts, move into the blood stream as

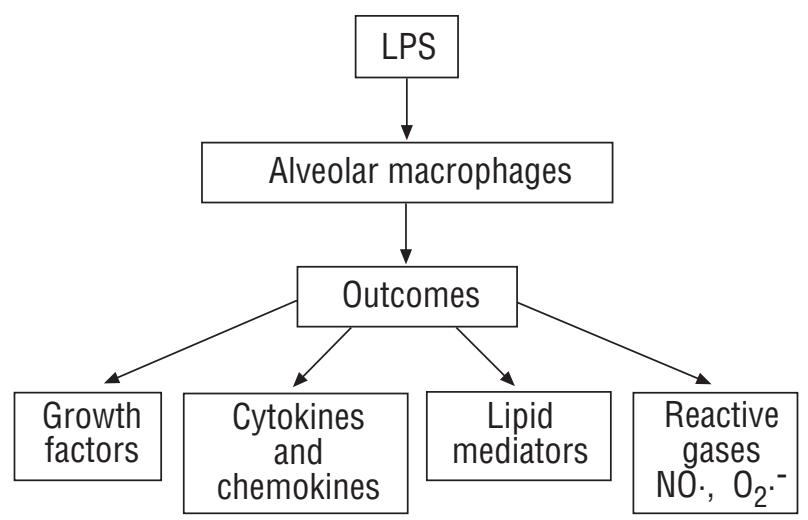

Fig. 1.-Alveolar macrophages respond to endotoxin (LPS) by the generation of inflammatory mediators. These include growth factors, cytokines, chemokines, lipids and reactive gases. NO nitric oxide; $\mathrm{O}_{2} \cdot^{-}$: superoxide radical. monocytes and finally move into the tissue and differentiate into resident macrophages [2].

The innate immune system (as opposed to the targeted antimicrobial response of the adaptive immune system) is the organism's first line of defense against microbial invasion. It functions to decrease tissue injury and death, promote recovery of the host, decrease secondary or opportunistic infections and interact with the adaptive immune system [3-6]. The principle components of the innate immune system include antimicrobial substances produced by epithelial cells, neutrophils, natural killer cells and macrophages. Macrophages are found in abundance at sites where organisms interact with the environment. Of the many types of macrophages found in the body, the alveolar macrophage has the most frequent contact with external stimuli. Each day, a human being breathes in and out more than 7,000 L of air [7]. This leads to a continual influx of organic and inorganic dusts and bacteria. The early recognition and response to invading pathogens by the alveolar macrophage is essential to survival. This early interaction between macrophage and environment results in the generation of signalling cascades, leading to the various effector functions that make up the initial immune response in the lung (fig. 1). This review focuses on the responses that occur following the interaction of endotoxin (LPS) from Gram-negative bacteria and macrophages, with a focus on the alveolar macrophage.

LPS is the principle activating component of the 
Gram-negative cell wall [8]. It is a potent molecule and is known to activate macrophages down to a level of $1 \mathrm{nM}$ [3]. JANEWAY and MEDZHITOV [9, 10] have defined components of the innate immune system, and by their classification, LPS is a pathogen-associated molecular pattern (PAMP). The cellular receptors that interact with PAMPs are known as pattern recognition receptors (PRRs). LPS interacts with particular PRRs on the macrophage surface. LPS contains an acylated diglucosamine head group (Lipid A) linked to a chain of repeating disaccharides. The Lipid A portion is responsible for the biological activity of LPS, while recent evidence suggests that the polysaccharide tail determines the antigenic properties [11, 12]. Interaction of LPS with a receptor complex on alveolar macrophages causes the sequential activation of multiple signalling pathways and transcription factors, resulting in gene transcription. This results in the orchestrated production of both proand anti-inflammatory mediators.

\section{Endotoxin receptors}

The major receptors found on the alveolar macrophage include scavenger receptors, Fc receptors, $G$ protein coupled receptors (GPCRs), integrins, CD14, Toll-like receptors (TLRs), cytokine receptors and chemokine receptors [13-19]. For LPS to interact with the macrophage it must first come into contact with LPS binding protein (LBP). LBP is required for an optimal LPS signal in macrophages. In in vitro experiments, LPS without LBP has only a fraction of its macrophage activating capabilities. LBP is a phospholipid transport protein that binds to Lipid A from LPS and presents it to receptor CD14. Shortly after the discovery of LBP [20-22], other studies [23, 24] identified CD14 as an important part of the LPS signalling pathway. Since that time, extensive biochemical and genetic data have confirmed an important role for CD14 in the macrophage response to LPS. Both LBP and CD14 knockout animals are partially resistant to the effects of LPS and to a lethal challenge by LPS $[25,26]$. CD14 is a membrane glycoprotein with a glycosylinositol (GPI) tail. It is present on alveolar macrophages and is also found as a soluble form that lacks the GPI tail [27-29]. CD14 is known to bind LPS, but the fact that it is anchored to the membrane with a GPI tail and contains no intracellular signalling moiety suggests a more complicated signalling complex.

The search for a signalling LPS receptor led to the discovery of Toll receptors. The gene encoding Toll was discovered in the 1980s as a Drosophila gene that affected dorsal/ventral patterning in the embryo [30]. A generation of mutant flies provided the information that this transmembrane protein was involved in the immune response to fungi $[31,32]$. Toll was shown to be part of a cascade, including spaetzle, Toll, tube, pelle and cactus, which controlled the production of antifungal peptides. Shortly after this, the first mammalian Toll receptor was described by Medzhitov et al. [33]. It was found on a monocyte cell line and shown to activate the transcription factor nuclear factor $-\kappa \mathrm{B}(\mathrm{NF}-\kappa \mathrm{B})$ and induce cytokine production.
Mammalian Toll is part of a homologous family of TLRs. Based on similarities in the cytoplasmic portion of the molecule, at least 10 different TLRs have been identified [34-39]. The initial description of human TLR by Medzhitov et al. [33] was followed by the observation that TLR2 was the CD14 associated LPS receptor $[40,41]$. These studies were weakened by later studies that identified TLR4 as the LPS-specific receptor. The link between TLR4 and LPS first appeared in a study showing that the genetic mutation responsible for LPS hyporesponsiveness in $\mathrm{C} 3 \mathrm{H} / \mathrm{Hej}$ mice was in the TLR4 gene [42]. Since that time, an additional study in LPS hyporesponsive mice C57BL10/ScNCr and LPS hyporesponsive humans has linked TLR4 mutations to the hyporesponsive phenotype [43-47]. Further in vitro evidence strengthened the link between LPS and TLR4, while at the same time showing that other TLRs are involved in responses to other bacterial products (TLRs 2, 1 and 6) and to bacterial deoxyribonucleic acid (DNA) (TLR9). Although it was not the LPS receptor, TLR2 has been linked to peptidoglycans from Gram positive bacteria, lipoteichoic acid, lipoarabinomannan from mycobacteria, and lipopeptides [3, 11, 48, 49]. Both TLR4 and TLR2 have been found on alveolar macrophages, providing the entry point for a complex cascade of LPS signalling [50].

In addition to the TLR complex, a number of other membrane receptors have been proposed to play a role in LPS signalling. These include the scavenger receptor, $\beta_{2}$-integrins, a purinergic receptor $\left(\mathrm{P}_{2} \mathrm{X}_{7}\right)$, moesin, triggering receptor expressed on myeloid cells (TREM-1) and a recently described complex that includes heat shock proteins 90 and 70, complement receptor 4 and bone morphogenic protein [51-56]. Early studies have suggested that high-dose LPS could signal through some of these other receptors independent of CD14 and TLR4. The TLR4-/- knockout data, however, suggests that the TLR4 receptor is essential for LPS signalling [43]. One possible explanation for the different data is that these other receptors might function as co-receptors and amplify the response after an initial CD14/TLR4 interaction with LPS. Further studies are necessary to definitively establish whether CD14/TLR4 independent signalling is possible. Several previous studies have suggested a role for the integrin receptors in LPS signalling [55, 57-59]. A recent paper by PERERA et al. [57] has shown that peritoneal macrophages from CD11b (a major $\beta_{2}$-integrin chain in macrophages) knockout mice have a decreased LPS response (some cytokines, cyclooxygenase (COX)2 and interleukin (IL)-12 p35, and a slight decrease in p38 activation). Because both in vivo and in vitro, the TLR4 knockout effect is so much greater than the effect of the $\beta_{2}$-integrin chain deletion, this review focuses on signalling downstream of the TLR4 complex.

\section{Proximal signalling}

The cytoplasmic domain of all TLRs shares significant sequence homology with the IL-1 and IL-18 receptors. This suggests a similar early signalling 
process after engagement of the receptor. The working model at this point is that LPS complexes with LBP, resulting in binding of CD14 and subsequent activation of TLR4 (with the assistance of a small secreted glycoprotein, MD-2) (fig. 2). Two recent studies have suggested a direct interaction of LPS and TLR4 [12, 60]. Downstream of TLR4, signalling resembles proximal IL-1 signalling, which includes the sequential recruitment of the adaptor protein MyD88 and IL-1 receptor-associated kinase (IRAK). Activated IRAK then returns to the cytoplasm where it activates tumour necrosis factor (TNF) receptor-associated factor 6 (TRAF6) [3, 6, 61]. Signals downstream of TLR4 fall into two classes, MyD88 dependent and MyD88 independent (fig. 2). Macrophages from MyD88-/- mice show the interesting phenotype of unimpaired or only decreased NF- $\mathrm{B}$ and mitogenactivated protein (MAP) kinase signalling and a total block of cytokine production [62]. This suggests that there are important signalling pathways that are independent of MyD88. A new adaptor protein (Toll/interleukin 1 receptor homology domain (TIR) containing adaptor protein (TIRAP)) has been identified that provides MyD88 independent signalling from TLR4 [63]. After the initial activation of the TLR4 complex, a number of signalling pathways are activated.

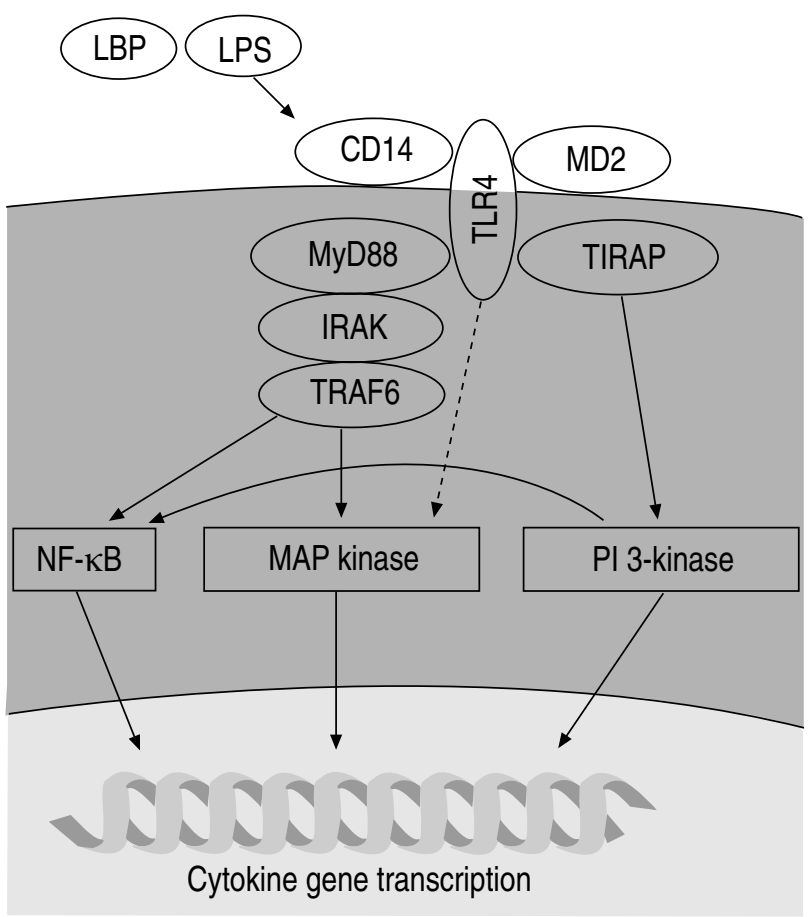

Fig. 2.-TLR4 signalling Endotoxin (LPS) first binds to the receptor CD14. This interaction results in the presentation of LPS to Toll-like receptor 4 (TLR4). This, in turn, triggers the formation of a signalling complex that includes MyD88, Toll/ interleukin (IL) 1 receptor homology domain containing adaptor protein (TIRAP), IL-1 receptor associated kinase (IRAK), and tumour necrosis factor receptor-associated factor (TRAF) 6 . Signalling downstream of this complex leads to activation of multiple pathways that regulate LPS-induced gene transcription. $\mathrm{NF}-\kappa \mathrm{B}$ : nuclear factor- $\mathrm{B}$; MAP: mitogen-activating protein; PI: phosphatidyinositol. LBP: LPS binding protein.
These include the MAP kinases, phosphatidylinositol (PI) 3-kinase pathway, and sphingolipid metabolites.

\section{Mitogen-activating protein kinesis}

The MAP kinases are a family of evolutionarily conserved enzymes that connect cell surface receptors to regulatory targets, which include both cytoplasmic and nuclear proteins. They can be activated by divergent stimuli, including hormones, growth factors, cytokines, GPCR agonists, tumour growth factor $\beta$ and TLR ligands [64]. They are activated by a threetiered cascade of kinases: 1) MAP kinase kinase kinase (MKKKs), of which there are many and a redundancy of function (for example MAP kinase kinase 4 (MEKK4) can be phosphorylated by at least 10 different MKKKs); 2) a suset of MKKK (MEKKs), of which there are only a few per MAP kinase; 3) MAP kinases themselves. The three major MAP kinase families are the extracellular signal-related kinase (ERK) (1 and 2), p38 ( $\alpha, \beta, \gamma$, and $\delta)$ and the c-Jun N-terminal kinase (JNK) (1, 2 and 3) [64]. All three of these are activated by LPS in alveolar macrophages. The MAP kinases are activated by phosphorylation of a threonine (Thr) X tyrosine (Tyr) conserved site in subdomain VII of the activation loop (ERK (Thr Glu Tyr), p38 (Thr Gly Tyr), and JNK (Thr Pro Tyr)) [65]. All MAP kinases recognise similar phosphoacceptor sites composed of a serine or threonine followed by a proline. The amino acids surrounding this site determine the specificity [64]. Activation of MAP kinases in alveolar macrophages is an early event after LPS contact, occuring within the first 15 min [66-69].

All three major MAP kinase families are activated by LPS in monocytic cells and all are involved in activation of transcription factors that are important for cytokine production [70-74]. The link between MAP-kinase activation and the production of inflammatory mediators has been studied extensively (fig. 3). The links to activator protein-1 (AP-1) shown in this figure complement the role of MAP kinases in NF- $\kappa \mathrm{B}$ activation.

JNK was initially identified by KYRIAKIS and coworkers $[75,76]$ as a p54 microtubule-associated protein that was activated by cycloheximide. A major substrate of JNK is c-Jun, a member of the AP-1 transcription factor dimer. JNK binds to c-Jun and phosphorylates it on serines 63 and 73 [77]. This phosphorylation is necessary for the transcriptional activity of c-Jun (rather than the DNA-binding activity) [78]. The involvement of MAP kinases (JNK-induced phosphorylation) in the transcriptional activity of a transcription factor as a process distinct from DNA binding is also found in studies on the activity of NF- $\mathrm{B}$ (see Transcription factors section). JNK also phosphorylates other AP-1 proteins, including Jun B, Jun D, and activating transcription factor-2 (ATF-2) [79]. While JNK phosphorylation of AP-1 proteins plays a positive role in transcriptional activity, AP-1 activity can also be negatively regulated by phosphorylation. Phosphorylation of c-Jun at the DNA binding domain (threonine 231, threonine 239, 


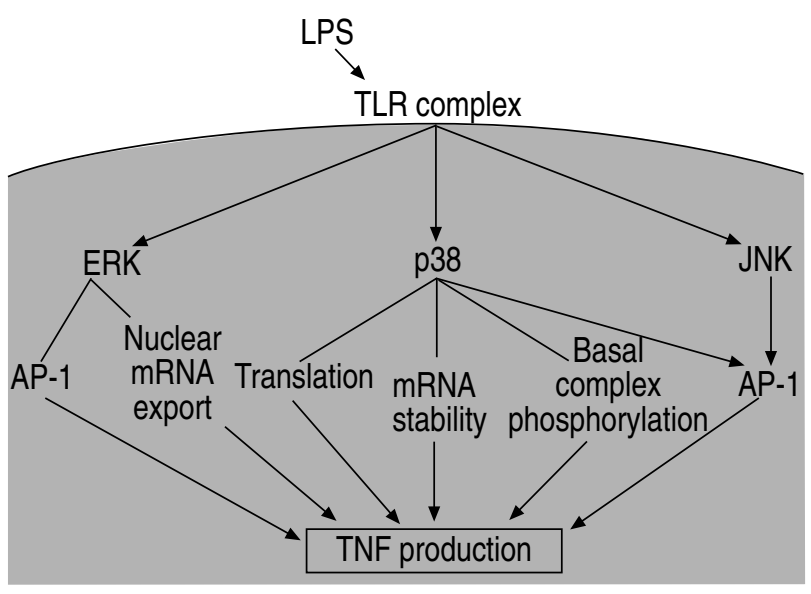

Fig. 3.-Mitogen-activating protein (MAP) kinases. MAP kinase activation by endotoxin (LPS) results in transcriptional activation of the tumour necrosis factor (TNF) gene and early release of TNF from the macrophage. Each of the MAP kinase pathways plays multiple and distinct roles in this event. TLR: Toll-like receptor; ERK: extracellular signal-related kinase; JNK: c-Jun N-terminal kinase; AP-1: activator protein-1; mRNA: messenger ribonucleic acid.

serine 243 and serine 249 ) by glycogen synthase kinase (GSK-3) or casein kinase 2 inhibits DNA binding $[80,81]$. In a study performed in LPS-treated alveolar macrophages, it was found that LPS inactivated GSK3 (a constitutively active kinase), suggesting that LPS regulation of AP-1 activity involves both activation (JNK) and blocking of constitutive inhibition (GSK-3) [82].

Direct p38 phosphorylation is linked with activity of the transcription factors ATF-2, stress-activated protein kinase 1a (Sapla) and myocyte enhancer binding factor (MEF) 2C family members [83]. p38 can phosphorylate ATF-2 at threonine 69 and serine 71 in the transcriptional domain, and this phosphorylation correlates with increased transcriptional activity [84]. Sapla is a member of the ternary complex factor (TCF) family and is phosphorylated by p38 on serines 381 and 387 [85-88]. The transcription factor MEF2C plays a role in c-Jun transcription and is phosphorylated and activated by p38 [83].

There are less direct links between ERK and transcription factor phosphorylation, although all of the MAP kinase family members phosphorylate and activate transcription factors of the ETS family that are involved in fos transcription. Phosphorylation of ELK-1 (a member of the ETS family) is a defining characteristic of ERK activation [89]. In addition, a recent paper by Young et al. [90] shows that ERK phosphorylates the AP-1 protein Fra-1 on threonine 231, suggesting involvement of ERK in the transcriptional activity of AP-1.

MAP kinases phosphorylate both cytoplasmic and nuclear substrates. Nontranscription factor effects of p38 include increasing messenger ribonucleic acid (mRNA) stability and phosphorylation of basal transcription complex components. p38 involvement in TNF mRNA stability was found both in a study by RutAult et al. [91] and in a study examining the mechanism of IL-10 mediated suppression of
LPS-induced TNF [92]. A role for p38 in translational regulation of cytokine production was found in a study of MAP kinase activating protein (MAPKAP)-2 (a kinase directly downstream of p38) knockout mice [93]. In the MAPKAP-2 knockout animals, LPSinduced septic shock resulted in $90 \%$ less TNF than in wild-type animals. However, the TNF mRNA levels were the same. The authors concluded that p38 and MAPKAP-2 were essential components of the biosynthesis of TNF at the post-transcriptional level, possibly having a role in the translation process. Production of other inflammatory mediators supports the role of p38 in mRNA stability. A study by DEAN et al. [94] demonstrates that p38 is essential for the stabilisation of COX2 mRNA.

Nontranscription factor effects of ERK have also been documented. In the cytoplasm, ERK has been shown to phosphorylate a diverse array of substrates: p90 ribosomal S6 kinase (p90RSK), cytosolic protein kinase A (PKA), tau, endothelial growth factor receptor (EGFR), Raf-1 and fos [64]. Tpl2 is a kinase that is necessary for ERK activation and Tpl2 knockout mice demonstrate a link between ERK kinase and TNF mRNA nuclear export [95]. Without ERK activity, TNF mRNA remained trapped in the nucleus, blocking subsequent protein production. This study suggests that ERK is involved in the export of cytokine mRNAs from the nucleus.

Many studies have addressed the issue of how LPS activation of mononuclear cells results in the activation of MAP-kinase pathways, including the ERK pathway [66-69]. The consensus pathway for ERK signalling has been defined as activation of the small GTPase Ras, which recruits the kinase Raf-1, which then activates the dual kinase MEK1 or 2, which phosphorylates a threonine and tyrosine in ERK 1 or 2. In murine RAW264.7 macrophages, GEPPERT et al. [96] demonstrated that LPS activated ERK and that dominant negative constructs of Ras or Raf-1 inhibited this activation as well as LPS-induced TNF production. A number of studies substantiated this observation, but not all studies supported a role for Raf-1 in LPS signalling to ERK [69].

Studies like GEPPERT et al. [96], which used overexpression of dominant negative constructs, generally concluded that LPS signals via Raf-1. In contrast, other studies have concluded that LPS activation of ERK is Raf-1 independent [69, 97, 98]. In a study performed by the current authors using normal human alveolar macrophages, LPS-induced ERK activation was found to be Raf-1 independent. LPS activated the atypical protein kinase $\mathrm{C}$ (PKC) isoform $\zeta$, and it was PKC $\zeta$ that activated MEK. The significance of an alternative pathway to ERK activation is currently being studied. It is possible that in alveolar macrophages, Raf-1 is involved in alternative signalling. For example, Raf- 1 has recently been shown to interact with and inhibit the apoptosis signal-regulating kinase 1 (ASK-1) [99]. This action of Raf-1 is independent of MEK and ERK.

LPS signalling to cytokine genes involves MAP kinases other than ERK. This was shown in a study by HAMBLETON et al. [100], which used a cell line with a Raf-1 chimeric protein that can be activated for 
prolonged time periods. With prolonged ERK activation there was very little production of TNF (20 times less) compared to LPS-treated cells, suggesting the need for pathways other than ERK for LPS-induced TNF production. The current authors found that in alveolar macrophages, optimal cytokine signalling (TNF and IL-6) involved both ERK and p38 MAP kinases [66]. If either ERK or p38 signalling were blocked with specific inhibitors, a partial block of cytokine transcription was found. If both inhibitors were used, there was a complete block. This has been confirmed in a recent study by RUTAULT et al. [91] who found that optimal TNF production required both ERK and p38. They also found that p38 was linked to an increase in TNF mRNA stability [91].

LPS has also been shown to activate the JNK MAP kinase [71], but less work has been done on the exact role of JNK in LPS signalling. The direct link between JNK and phosphorylation of the proteins involved in AP-1 generation links this kinase to cytokine production and further studies will no doubt refine this knowledge.

\section{Phosphatidylinositol 3-kinase pathway}

Until the 1970s lipids were considered inert structural parts of cell membranes. This began to change with discovery of the phosphoinositide cycle [101, 102]. Since that time, signalling functions for multiple classes of lipids, including phosphoinositides and arachidonic acid metabolites, have been demonstrated. A lipid signalling pathway with a definitive role in LPS signalling is the PI 3-kinase pathway (fig. 3) [82, 103]. Membrane-associated PI 3-kinase catalyses the transfer of adenosine trisphosphate to the D-3 position of the inositol ring of membrane-localised phosphoinositides [104]. This results in the production of a number of bioactive species including phosphatidylinositol 3 phosphate $\left(\mathrm{PI}_{3} \mathrm{P}\right)$, phosphatidylinositol 3,4 phosphate $\left(\mathrm{PI}_{3,4} \mathrm{P}\right)$, and phosphatidylinositol 3,4,5 phosphate $\left(\mathrm{PI}_{3,4,5} \mathrm{P}\right)$. Both $\mathrm{PI}_{3,4} \mathrm{P}$ and $\mathrm{PI}_{3,4,5} \mathrm{P}$ are nominally absent in most unstimulated cells and increase dramatically following PI 3-kinase activation. The production of $\mathrm{PI}_{3,4,5} \mathrm{P}$, especially, results in the recruitment of 3-phosphoinositide-dependent kinase (PDK-1), a kinase with multiple downstream substrates, including protein kinase B (Akt) (fig. 4) [105].

Akt, like PDK-1, is recruited to membrane-bound D-3 phosphorylated phosphatidylinositols (D-3 PPIs) by its pleckstrin homology $(\mathrm{PH})$ domain. Binding of Akt to D-3 PPIs results in a conformational change allowing phosphorylation by PDK-1 (on threonine 308 in the activation loop) and an activating phosphorylation at serine 473 within the hydrophobic motif at the kinase tail [106]. Activation of Akt results in the phosphorylation of a number of substrates that have potential importance in LPS signalling (GSK-3, Bad, caspase 9, Forkhead transcription factors, Raf-1, inhibitor of $\kappa \mathrm{b}(\mathrm{I} \kappa \mathrm{B})$ kinase, phosphodiesterase (PDE)$3 \mathrm{~B}$ and endothelial nitric oxide synthase (eNOS)) [104, $106,107]$. Phosphorylation of these proteins by Akt results in either activation or inactivation depending on the substrate. Inactivation of some of the

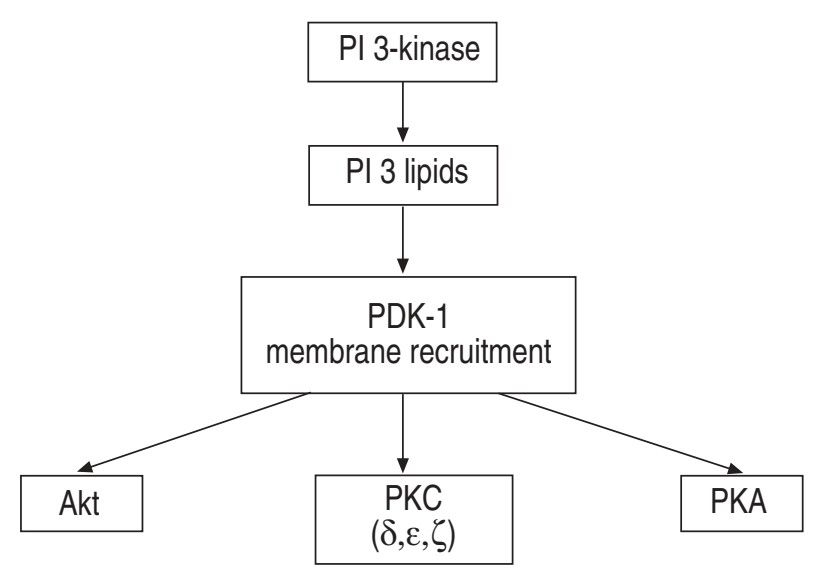

Fig. 4.-Activation of phosphatidylinositol (PI) 3-kinase results in a signalling cascade that begins with the production of phosphatidylinositol $3,4,5$. This leads to the membrane recruitment of 3-phosphoinositide-dependent kinase (PDK)-1 and other downstream kinases. PDK-1 phosporylates these substrates in their activation domains generating active kinases. These kinases then phosphorylate further substrates, amplifying the initial PI 3-kinase activity several times. Akt: protein kinase B; PKC: protein kinase C; PKA: protein kinase A.

pro-apoptotic factors (caspase 9, Bad, GSK-3 and the Forkhead family of transcription factors) is central to Akt's role in cell survival [108-111].

Activation of PI 3-kinase was first described as being downstream of tyrosine kinases. SH2 domains in the p85 regulatory unit of Class I PI 3-kinase were found to bind to phosphotyrosines in the cytoplasmic domain of growth factor receptors initiating signalling [112]. This results in the membrane recruitment of the p110 catalytic unit and subsequent signalling. LPS activation of PI 3-kinase was first described by Herrera-Velit et al. [113]. They found that in monocytes, LPS caused a rapid activation of PI 3-kinase that was accompanied by the production of D-3 PPIs. A second study by the same group showed that the LPS-induced PI 3-kinase activity was linked to activation of PKC via PDK-1 [114]. This is consistent with the findings of the current authors in alveolar macrophages when ERK activation was linked to PKC $\zeta$ [69]. It was found that LPS caused an association between PKC $\zeta$ and PDK-1 that temporally coincided with activation. Since that time, two further studies in alveolar macrophages examining activation of PI 3-kinase by LPS have been completed. In the first of these studies, the current authors showed that LPS activated PI 3-kinase and the downstream kinase Akt [82]. This resulted in a link to GSK-3 inactivation and the nuclear accumulation of $\beta$ catenin. $\beta$ Catenin driven genes include cyclin D1, c-myc, fra 1 and connexin 43. Both activation of Akt and inactivation of GSK-3 are linked to cell survival and next a link between LPS activation of PI 3-kinase and cell survival in alveolar macrophages was demonstrated [103].

Having shown some of the events downstream of LPS induced PI 3-kinase activity, the current authors then evaluated the link between the TLR complex and activation of PI 3-kinase. A group at Scripps Research Institute (La Jolla, CA, USA) looking at the 
link between TLR2 (Gram-positive signalling) and PI 3-kinase activation [115] found a p85 binding site on the cytoplasmic domain of TLR 2 . They linked TLR signalling to direct recruitment of $\mathrm{p} 85$ to the receptor and activation of PI 3-kinase. TLR 4 lacks this domain and in alveolar macrophages it was found that LPS signalled PI 3-kinase via the generation of ceramide. In addition, it was found that the ceramide-induced PI 3-kinase activation masked the normal apoptotic function of ceramide and turned what could have been a cell death-inducing event (the generation of ceramide) into a non-apoptotic event (activation of ERK and PI 3-kinase with its downstream kinases). In addition to regulating cell survival, the PI 3-kinase dependent kinase, Akt, is linked to activation of the transcription factor NF- $\kappa \mathrm{B}$. This will be dealt with more completely in the section on LPS regulation of the major cytokine-linked transcription factors.

\section{Sphingolipids}

The authors' studies in alveolar macrophages have demonstrated a link between LPS-generated ceramide and activation of both the ERK MAP kinase and PI 3-kinase. Ceramide is only one of many sphingolipids that have potential signalling capacity, but it is the one that has the strongest demonstrated link with LPS signalling. Sphingolipids are defined by the presence of a sphingoid backbone (fig. 5) [116]. Ceramide is sphingosine acylated at the 2-amino acid position. Sphingolipids are synthesised in the endoplasmic reticulum (ER) and the golgi. Ceramide can be generated by de novo synthesis initiated with the condensation of serine and palmitoyl-CoA, catalysed by serine palmitoyltransferase and ending with the conversion of dihydroceramide to ceramide by dihydroceramide reductase [116]. Ceramide produced in the ER is moved to the golgi, where sphingomyelin synthase transfers the phosphocholine headgroup from phosphatidylcholine to the hydroxy group of ceramide, producing sphingomyelin. Sphingomyelin then moves to the plasma membrane where most is found on the outer leaflet. More particularly, sphingomyelin is especially prevalent in rafts or caveolae, plasma membrane structures that have been linked to signalling cascades [117]. Some macrophage receptors have been localised to caveolae (CD14 and GPCR, for example), possibly linking LPS signalling to alterations in the lipid component of macrophage membranes.

Ceramide involved in signalling is not generated by de novo synthesis but rather triggered within minutes via the action of neutral and acid sphingomyelinases $[116,118,119]$. These enzymes convert sphingomyelin (on the plasma membrane or on lysosomal membranes) to ceramide (fig. 4). Sphingomyelinase-generated ceramide is found after cellular exposure to a diverse array of stimuli, including TNF- $\alpha$, Fas ligand, dexamethasone, nitric oxide, IL-1 $\beta$, interferon $\gamma$ and LPS [116]. Many of these events are pro-apoptotic. LPSinduced ceramide in alveolar macrophages is one of the few places that ceramide generation has been linked to cell survival [103]. How ceramide activates

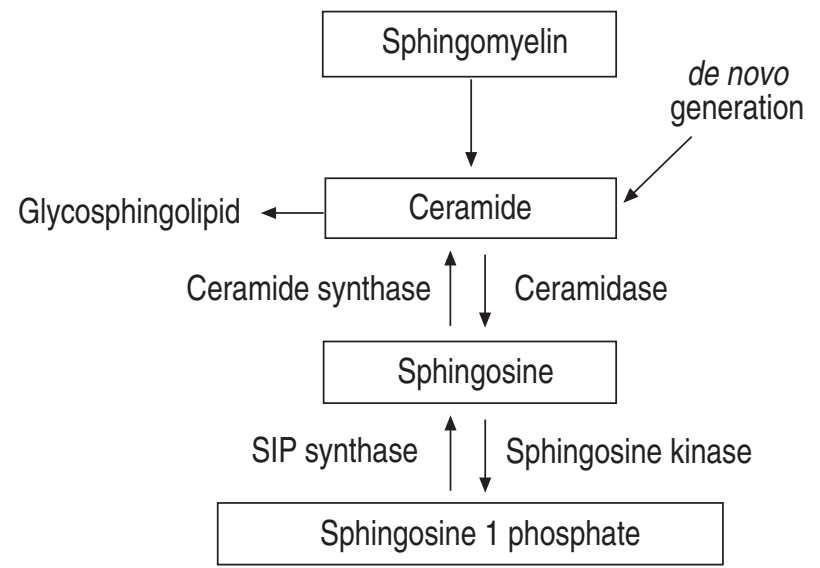

Fig. 5.-Sphingolipid metabolism. A diagram of a possible ceramide-generated sphingolipid pathway in alveolar macrophages. Ceramide can be rapidly converted to sphingosine and sphingosine 1 phosphate and just as rapidly converted back depending on the presence and activity of the converting enzymes. SIP: sphingosine 1 phosphate.

signalling cascades has not been clearly defined. Two possible downstream mediators are ceramide-activated proline-directed kinase [120] and ceramide-activated protein phosphatase [116]. Other possible links include novel and atypical PKC isoforms, c-Raf and protein phosphatase 1B (PP1B) [121].

Other sphingolipids that may be involved in LPS signalling include sphingosine, generated by the actions of ceramidases on ceramide, and sphingosine 1 phosphate, generated by the actions of sphingosine kinase on sphingosine (fig. 4). Sphingosine was first described as an inhibitor of PKC [122]. This was an in vitro observation and there is some question about how relevant this is to the in vivo system [123]. Sphingosine has been shown to mediate cell growth arrest by dephosphorylating retinoblastoma $(\mathrm{Rb})$, and increases in sphingosine are linked to apoptosis in many systems [124, 125]. In contrast, sphingosine 1 phosphate has been linked to cell survival [126-128]. While a number of studies, including those of the current authors, have linked LPS to the generation of ceramide in macrophages $[68,69,103,129-131]$, there is as yet no data on the possible role of these ceramide metabolites in LPS signalling. This is likely to provide a fruitful area of research in the future.

\section{Transcription factors}

The end result of the signalling generated by LPS in macrophages is activation of transcription factors and the resulting production of both pro- and antiinflammatory mediators. This review focuses on the transcription factor NF- $\kappa \mathrm{B}$ because of the significant role it plays in the production of many inflammatory mediators. NF- $\mathrm{NB}$ activation has been linked to production of TNF- $\alpha$, IL-1 $\beta$, IL-6, IL-8, COX2, intracellular adhesion molecule (ICAM)-1 and collagenase, to name just a few of the genes with active $\mathrm{NF}-\kappa \mathrm{B}$ sites [132]. LPS was first shown to activate $\mathrm{NF}-\kappa \mathrm{B}$ in monocytic cells in a study by Muller et al. 
[133]. Since that time, NF- $\mathrm{B}$ B regulation after LPS has been the subject of intense study. What has emerged from these studies is the idea that there are multiple regulatory pathways involved in generating $\mathrm{NF}-\kappa \mathrm{B}$ driven transcription. Regulation can be divided into four different areas: nuclear translocation, phosphorylation of Rel family proteins, interaction with the basal transcription complex and redox regulation.

The NF- $\kappa \mathrm{B} / \mathrm{Rel}$ family of genes includes p50, p105, p52, p65 (Rel A), Rel B, and c-Rel. The primary NF$\kappa \mathrm{B}$ dimer involved in LPS signalling is a p65/p50 heterodimer $[134,135]$. NF- $\kappa \mathrm{B}$ proteins reside in the cytoplasm in an inactive state, kept there by IкBs. The IкB family includes $\alpha, \beta$, and $\varepsilon$ isoforms and the $\alpha$ isoform has been most closely linked to LPS signals

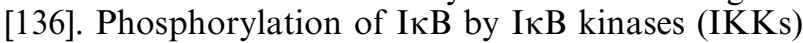
results in the ubiquitination of $I \kappa \mathrm{B}$. I $\kappa \mathrm{B}$ is then degraded by the $26 \mathrm{~S}$ proteosome releasing $\mathrm{NF}-\kappa \mathrm{B}$ proteins to move to the nucleus [137]. The IKK complex includes IKK $\alpha, \beta$ and a structural/regulatory component, $\gamma$ [138]. IKK $\beta$ has been identified as the primary IKK involved in LPS activation of $\mathrm{NF}-\kappa \mathrm{B}$ in monocytic cells [139-141]. Phosphorylation and activation of IKK $\beta$ by an upstream kinase leads to NF- $\kappa \mathrm{B}$ localisation in the nucleus (fig. 6a). Looking upstream of IKK $\beta$, there have been a number of proteins identified as possible IKKs. These include NF- $\kappa \mathrm{B}$ inducing kinase (NIK), transforming growth factor- $\beta$-activating kinase (TAK) 1, MEKK1, MEKK2, MEKK3 and Akt (a member of the PI 3-kinase pathway) [142-144]. SWANTEK et al. [141] demonstrated that negative mutants of NIK, TAK1 and Akt blocked LPS activation of $\mathrm{NF}-\kappa \mathrm{B}$ in murine RAW264.7 cells. Several studies have defined NIK as the upstream kinase responsible for $\mathrm{NF}-\kappa \mathrm{B}$ activation, but studies in alymphoplasia (ala) mice, which contain a disrupting point mutation in NIK, show no effect on NF- $\kappa B$ activation by TNF [145]. This has led to an increased interest in defining IKKs. One recent study has linked TRAF6, from the TLR pathway, to evolutionarily conserved signalling intermediate in Toll pathways (ECSIT)-MEKK1IKK $\beta$ [146]. Another possible TRAF6 signalling sequence is TRAF6 to TAK1-binding protein (TAB) 2-TAK1-IKK $\beta$ [147].

Nuclear localisation is only one of the events that needs to happen for successful $\mathrm{NF}-\kappa \mathrm{B}$ driven gene transcription. Several studies have shown that p65 must be phosphorylated for transcriptional competence (fig. 6b). An early study by СовB et al. [148] showed that a phosphocholine specific phospholipase $\mathrm{C}$ (PC-PLC) inhibitor could block NF- $\kappa \mathrm{B}$ without blocking transcription. A study by YozA et al. [149] demonstrated that tyrosine kinase inhibitors also blocked transcription without blocking translocation. Finally, a number of studies have linked MAP kinases to transcriptional activity independent of translocation $[66,89,150,151]$. Possible upstream kinases of p65 include PKA, the atypical PKC isoform $\zeta$ and Akt [150, 152, 153].

Translocation and phosphorylation provide one level of regulation. A third level is redox regulation. In 1992, Matthews et al. [154] showed that NF-кB DNA binding was inhibited by $\mathrm{SH}$ modifying agents and enhanced by reducing agents. Thioredoxin (an

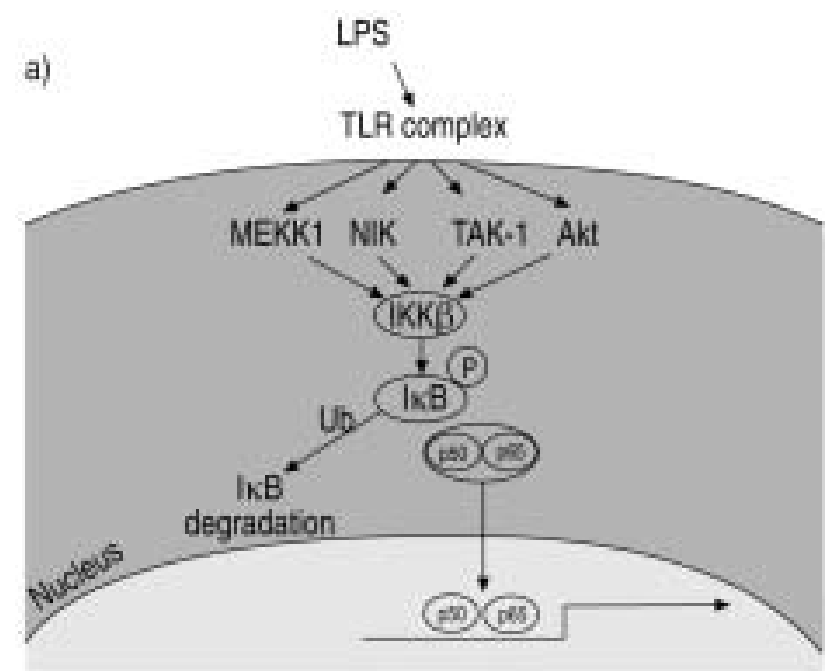

b)

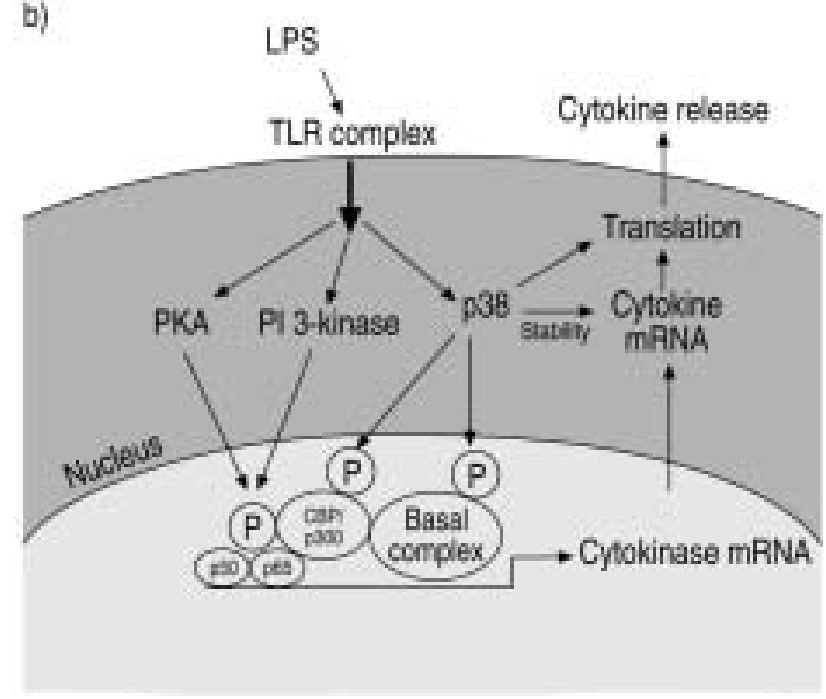

Fig. 6. - Nuclear factor $-\kappa \mathrm{B}(\mathrm{NF}-\kappa \mathrm{B})$ activation is regulated at multiple levels. a) Events that lead to the nuclear translocation of NF-kB. b) Events that regulate the transcriptional activity of NF$\mathrm{kB}$ once it reaches the nucleus. LPS: endotoxin; TLR: Toll-like receptor; MEKK: a subset of mitogen-activating protein kinase kinase kinase; NIK: NF- $\mathrm{BB}$ inducing kinase; TAK: transforming growth factor- $\beta$-activating kinase; Akt: protein kinase $\mathrm{B}$; IKK: inhibitors of $\kappa \mathrm{B}(\mathrm{I} \kappa \mathrm{B})$ kinases; PI 3: phosphatidylinsositol 3; mRNA: messenger ribonucleic acid; CBP: cAMP response element binding protein; PKA: protein kinase A.

oxidoreductase with antioxidant properties) was identified as the protein that modified a cysteine residue in the p50 NF- $\kappa \mathrm{B}$ subunit, which allowed DNA binding. A more recent study has shown that thioredoxin plays a dual and opposing role in NF- $\kappa \mathrm{B}$ regulation. In cytosol, antioxidants, including thioredoxin, decrease activation of IKK $\beta$ and $\mathrm{NF}-\kappa \mathrm{B}$ translocation, but after cell activation, thioredoxin moves to the nucleus where it plays a positive role in NF- $\kappa \mathrm{B}$ activity [155]. These studies have mostly been done with stimuli other than LPS and with cells other than macrophages.

Besides thioredoxin, another protein involved in redox regulation of transcription factors is Ref- 1 . Redox regulation of AP-1 proteins by Ref-1 is 
necessary for optimal DNA binding and transcriptional activity of AP-1. The current authors performed a study in alveolar macrophages evaluating redox regulation of the transcription factor AP-1 (also activated by LPS and involved in cytokine regulation) [156]. Alveolar macrophages were deficient in Ref-1 and this deficiency resulted in decreased AP-1 DNA binding after macrophage activation. In addition, it was found that the growth factor granulocyte-macrophage colony-stimulating factor (GM-CSF) upregulates amounts of Ref-1 in alveolar macrophages. This leads to increased AP-1 DNA binding after stimulation of alveolar macrophages [157]. The exact role played by thioredoxin and Ref-1 in LPS signalling in alveolar macrophages needs further study.

A final point of regulation of $N F-\kappa B$-driven transcription is the need for $\mathrm{NF}-\kappa \mathrm{B}$ binding to members of the complex at the transcription start site. Necessary binding of $\mathrm{NF}-\kappa \mathrm{B}$ to co-activators has been shown for the transcription factor cyclic adenosine monophosphate response element binding protein (CBP)/ p300 and for the two transcription complex proteins TATA binding proteins (TBP) and transcription factor IIB (TFIIB) [66, 89, 153, 158, 159]. It has been shown that LPS-induced NF- $\kappa \mathrm{B}$ transcription (a distinct form of DNA binding or p65 phosphorylation) requires phosphorylation of TFIID (TBP) via activation of the p38 MAP kinase pathway (fig. 6b) $[66,89]$. The authors found that optimal NF- $\kappa \mathrm{B}$ transcription after LPS required p38-dependent phosphorylation of TBP. Inhibition of p38 had no effect of NF- $\kappa \mathrm{B}$ translocation or DNA binding but it did block phosphorylation of TBP. This study demonstrates that LPS-induced p38 activation plays a role in the regulation of $\mathrm{NF}-\kappa \mathrm{B}$ activity via phosphorylation of a protein in the basal transcription complex.

Termination of $\mathrm{NF}-\kappa \mathrm{B}$ signalling is a complex event. A large role is played by the rapid resynthesis of $I \kappa B \alpha$ [135]. Blocking of $\mathrm{I} \kappa \mathrm{B}$ transcription in LPS-treated cells results in the accumulation of $N F-\kappa B$ [160]. When LPS-induced $\mathrm{I} \kappa \mathrm{B}$ transcription is allowed to proceed, I $\kappa \mathrm{Ba}$ then binds to $\mathrm{NF}-\kappa \mathrm{B}$ in the nucleus and the $\mathrm{I} \kappa \mathrm{B} / \mathrm{NF}-\kappa \mathrm{B}$ complex shuttles back to the cytoplasm via a nuclear export signal in I $\mathrm{KB}$. LPS activation of $\mathrm{NF}-\kappa \mathrm{B}$ in alveolar macrophages is a rapid process. The authors have found nuclear localisation as early as $30 \mathrm{~min}$, with a peak of 1-3 h. Release of TNF happens quickly and is followed shortly by other inflammatory mediators. The process that shuts down $\mathrm{NF}-\kappa \mathrm{B}$ activation in LPS treated alveolar macrophages involves the resynthesis of $I \kappa B \alpha$, but other mechanisms may arise from further studies.

\section{Conclusion}

Endotoxin signalling in alveolar macrophages results in a complex cascade of events resulting in the rapid production of first pro-inflammatory mediators and then more slowly, the production of mediators that slow or stop the inflammatory process. Activation of the innate immune system by endotoxin provides a first line of host defense ultimately controlling the initiation and determination of the adaptive immune response that follows. Significant advances have been made in understanding the pathways that lead to the macrophage response but many things remain to be learned.

\section{References}

1. Karnovsky ML. Metchnikoff in Messina: a century of studies on phagocytosis. N Engl J Med 1981; 304: 1178-1180.

2. van Furth R. Origin and turnover of monocytes and macrophages. Curr Top Pathol 1989; 79: 125-150.

3. Aderem A, Ulevitch RJ. Toll-like receptors in the induction of the innate immune response. Nature 2000; 406: 782-787.

4. Beutler B. Endotoxin, toll-like receptor 4, and the afferent limb of innate immunity. Curr Opin Microbiol 2000; 3: 23-28.

5. Beutler B. Sepsis begins at the interface of pathogen and host. Biochem Soc Trans 2001; 29: 853-859.

6. Medzhitov R, Janeway C Jr. Innate immunity. $N$ Engl $J$ Med 2000; 343: 338-344.

7. Martin TR. Recognition of bacterial endotoxin in the lungs. Am J Respir Cell Mol Biol 2000; 23: 128132.

8. Darveau RP. Lipid A diversity and the innate host response to bacterial infection. Curr Opin Microbiol 1998; 1: 36-42.

9. Janeway CA Jr, Medzhitov R. Introduction: the role of innate immunity in the adaptive immune response. Semin Immunol 1998; 10: 349-350.

10. Medzhitov R, Janeway CA Jr. An ancient system of host defense. Curr Opin Immunol 1998; 10: 12-15.

11. Lien E, Means TK, Heine $\mathrm{H}$, et al. Toll-like receptor 4 imparts ligand-specific recognition of bacterial lipopolysaccharide. J Clin Invest 2000; 105: 497504.

12. Poltorak A, Ricciardi-Castagnoli P, Citterio S, Beutler B. Physical contact between lipopolysaccharide and toll-like receptor 4 revealed by genetic complementation. Proc Natl Acad Sci USA 2000; 97: 2163-2167.

13. Kodama T, Freeman M, Rohrer L, Zabrecky J, Matsudaira P, Krieger M. Type I macrophage scavenger receptor contains alpha-helical and collagen-like coiled coils. Nature 1990; 343: 531-535.

14. Vejlsgaard GL, Ralfkiaer E, Avnstorp C, Czajkowski M, Marlin SD, Rothlein R. Kinetics and characterization of intercellular adhesion molecule-1 (ICAM-1) expression on keratinocytes in various inflammatory skin lesions and malignant cutaneous lymphomas. J Am Acad Dermatol 1989; 20: 782-790.

15. Kishimoto TK, Larson RS, Corbi AL, Dustin ML, Staunton DE, Springer TA. The leukocyte integrins. Adv Immunol 1989; 46: 149-182.

16. Guy K, Middleton PG, Docherty LJ, De Angelis CL, Steel CM. MHC class II antigen and immunoglobulin expression in spontaneous phenotypic variants of the Burkitt's lymphoma cell line Namalwa. Immunology 1986; 59: 603-610.

17. Haziot A, Chen S, Ferrero E, Low MG, Silber R, Goyert SM. The monocyte differentiation antigen, CD14, is anchored to the cell membrane by a phosphatidylinositol linkage. J Immunol 1988; 141: 547-552.

18. Beutler B, Poltorak A. Toll we meet again. Nat Immunol 2001; 2: 9-10.

19. Means TK, Golenbock DT, Fenton MJ. The biology 
of Toll-like receptors. Cytokine Growth Factor Rev 2000; 11: 219-232.

20. Schumann RR, Leong SR, Flaggs GW, et al. Structure and function of lipopolysaccharide binding protein. Science 1990; 249: 1429-1431.

21. Schumann RR. Function of lipopolysaccharide (LPS)binding protein (LBP) and CD14, the receptor for LPS/LBP complexes: a short review. Res Immunol 1992; 143: 11-15.

22. Schumann RR, Rietschel ET, Loppnow H. The role of $\mathrm{CD} 14$ and lipopolysaccharide-binding protein (LBP) in the activation of different cell types by endotoxin. Med Microbiol Immunol (Berl) 1994; 183: 279-297.

23. Wright SD, Ramos RA, Tobias PS, Ulevitch RJ, Mathison JC. CD14, a receptor for complexes of lipopolysaccharide (LPS) and LPS binding protein. Science 1990; 249: 1431-1433.

24. Lee JD, Kravchenko V, Kirkland TN, et al. Glycosylphosphatidylinositol-anchored or integral membrane forms of CD14 mediate identical cellular responses to endotoxin. Proc Natl Acad Sci USA 1993; 90: 9930 9934.

25. Heinrich JM, Bernheiden M, Minigo G, et al. The essential role of lipopolysaccharide-binding protein in protection of mice against a peritoneal Salmonella infection involves the rapid induction of an inflammatory response. J Immunol 2001; 167: 1624 1628.

26. Ebong SJ, Goyert SM, Nemzek JA, Kim J, Bolgos GL, Remick DG. Critical role of CD14 for production of proinflammatory cytokines and cytokine inhibitors during sepsis with failure to alter morbidity or mortality. Infect Immun 2001; 69: 2099-2106.

27. Tapping RI, Tobias PS. Soluble CD14-mediated cellular responses to lipopolysaccharide. Chem Immunol 2000; 74: 108-121.

28. Takeshita S, Nakatani K, Tsujimoto H, Kawamura Y, Sekine I. Detection of circulating lipopolysaccharidebound monocytes in children with gram-negative sepsis. J Infect Dis 2000; 182: 1549-1552.

29. Kitchens RL, Thompson PA, Viriyakosol S, O'Keefe GE, Munford RS. Plasma CD14 decreases monocyte responses to LPS by transferring cell-bound LPS to plasma lipoproteins. J Clin Invest 2001; 108: 485-493.

30. Stein D, Roth S, Vogelsang E, Nusslein-Volhard C. The polarity of the dorsoventral axis in the Drosophila embryo is defined by an extracellular signal. Cell 1991; 65: 725-735.

31. Lemaitre B, Reichhart JM, Hoffmann JA. Drosophila host defense: differential induction of antimicrobial peptide genes after infection by various classes of microorganisms. Proc Natl Acad Sci USA 1997; 94: 14614-14619.

32. Lemaitre B, Nicolas E, Michaut L, Reichhart JM, Hoffmann JA. The dorsoventral regulatory gene cassette spatzle/Toll/cactus controls the potent antifungal response in Drosophila adults. Cell 1996; 86: 973-983.

33. Medzhitov R, Preston-Hurlburt P, Janeway CA Jr. A human homologue of the Drosophila Toll protein signals activation of adaptive immunity. Nature 1997; 388: 394-397.

34. Rock FL, Hardiman G, Timans JC, Kastelein RA, Bazan JF. A family of human receptors structurally related to Drosophila Toll. Proc Natl Acad Sci USA 1998; 95: 588-593.
35. Hemmi H, Takeuchi O, Kawai T, et al. A Toll-like receptor recognizes bacterial DNA. Nature 2000; 408: $740-745$.

36. Takeuchi $\mathrm{O}$, Hoshino $\mathrm{K}$, Kawai $\mathrm{T}$, et al. Differential roles of TLR2 and TLR4 in recognition of gram-negative and gram-positive bacterial cell wall components. Immunity 1999; 11: 443-451.

37. Takeuchi O, Kawai T, Sanjo H, et al. TLR6: A novel member of an expanding toll-like receptor family. Gene 1999; 231: 59-65.

38. Chuang T, Ulevitch RJ. Identification of hTLR10: a novel human Toll-like receptor preferentially expressed in immune cells. Biochim Biophys Acta 2001; 1518: 157161.

39. Chuang TH, Ulevitch RJ. Cloning and characterization of a sub-family of human toll-like receptors: hTLR7, hTLR8 and hTLR9. Eur Cytokine Netw 2000; 11: 372-378.

40. Yang RB, Mark MR, Gray A, et al. Toll-like receptor2 mediates lipopolysaccharide-induced cellular signalling. Nature 1998; 395: 284-288.

41. Kirschning CJ, Wesche H, Merrill Ayres T, Rothe M. Human toll-like receptor 2 confers responsiveness to bacterial lipopolysaccharide. J Exp Med 1998; 188: 2091-2097.

42. Poltorak A, He X, Smirnova I, Liu MY, et al. Defective LPS signaling in $\mathrm{C} 3 \mathrm{H} / \mathrm{HeJ}$ and $\mathrm{C} 57 \mathrm{BL} /$ $10 \mathrm{ScCr}$ mice: mutations in Tlr4 gene. Science 1998; 282: 2085-2088.

43. Hoshino K, Takeuchi O, Kawai T, et al. Cutting edge: Toll-like receptor 4 (TLR4)-deficient mice are hyporesponsive to lipopolysaccharide: evidence for TLR4 as he Lps gene product. J Immunol 1999; 162: 37493752.

44. Qureshi ST, Gros P, Malo D. Host resistance to infection: genetic control of lipopolysaccharide responsiveness by TOLL-like receptor genes. Trends Genet 1999; 15: 291-294.

45. Qureshi ST, Gros P, Malo D. The Lps locus: genetic regulation of host responses to bacterial lipopolysaccharide. Inflamm Res 1999; 48: 613-620.

46. Qureshi ST, Lariviere L, Leveque G, et al. Endotoxintolerant mice have mutations in Toll-like receptor 4 (Tlr4). J Exp Med 1999; 189: 615-625.

47. Arbour NC, Lorenz E, Schutte BC, et al. TLR4 mutations are associated with endotoxin hyporesponsiveness in humans. Nat Genet 2000; 25: 187-191.

48. Rhee SH, Hwang D. Murine TOLL-like receptor 4 confers lipopolysaccharide responsiveness as determined by activation of NF kappa $\mathrm{B}$ and expression of the inducible cyclooxygenase. J Biol Chem 2000; 275: 34035-34040.

49. Tapping RI, Akashi S, Miyake K, Godowski PJ, Tobias PS. Toll-like receptor 4, but not toll-like receptor 2, is a signaling receptor for Escherichia and Salmonella lipopolysaccharides. J Immunol 2000; 165: 5780-5787.

50. Means TK, Jones BW, Schromm AB, et al. Differential effects of a Toll-like receptor antagonist on Mycobacterium tuberculosis-induced macrophage responses. J Immunol 2001; 166: 4074-4082.

51. $\mathrm{Hu} \mathrm{Y,} \mathrm{Fisette} \mathrm{PL,} \mathrm{Denlinger} \mathrm{LC,} \mathrm{et} \mathrm{al.} \mathrm{Purinergic}$ receptor modulation of lipopolysaccharide signaling and inducible nitric-oxide synthase expression in RAW 264.7 macrophages. J Biol Chem 1998; 273: 27170-27175.

52. Nathan C, Ding A. TREM-1: a new regulator of 
innate immunity in sepsis syndrome. Nat Med 2001; 7: $530-532$.

53. Triantafilou K, Triantafilou M, Dedrick RL. A CD14independent LPS receptor cluster. Nat Immunol 2001; 2: $338-345$.

54. Tohme ZN, Amar S, Van Dyke TE. Moesin functions as a lipopolysaccharide receptor on human monocytes. Infect Immun 1999; 67: 3215-3220.

55. Ingalls $\mathrm{RR}$, Monks $\mathrm{BG}$, Savedra $\mathrm{R} \mathrm{Jr}$, et al. CD11/CD18 and CD14 share a common lipid A signaling pathway. J Immunol 1998; 161: 5413-5420.

56. Kobayashi Y, Miyaji C, Watanabe $\mathrm{H}$, et al. Role of macrophage scavenger receptor in endotoxin shock. J Pathol 2000; 192: 263-272.

57. Perera PY, Mayadas TN, Takeuchi O, et al. CD11b/CD18 acts in concert with CD14 and Toll-like receptor (TLR) 4 to elicit full lipopolysaccharide and taxol-inducible gene expression. J Immunol 2001; 166: $574-581$.

58. Schmidt A, Caron E, Hall A. Lipopolysaccharideinduced activation of beta2-integrin function in macrophages requires Irak kinase activity, p38 mitogen-activated protein kinase, and the Rap1 GTPase. Mol Cell Biol 2001; 21: 438-448.

59. Flo TH, Ryan L, Kilaas L, et al. Involvement of CD14 and beta2-integrins in activating cells with soluble and particulate lipopolysaccharides and mannuronic acid polymers. Infect Immun 2000; 68: 6770 6776.

60. da Silva Correia J, Soldau K, Christen U, Tobias PS, Ulevitch RJ. Lipopolysaccharide is in close proximity to each of the proteins in its membrane receptor complex. Transfer from CD14 to TLR4 and MD-2. J Biol Chem 2001; 276: 21129-21135.

61. Medzhitov R, Janeway C Jr. The Toll receptor family and microbial recognition. Trends Microbiol 2000; 8: 452-456.

62. Kawai T, Adachi O, Ogawa T, Takeda K, Akira S. Unresponsiveness of MyD88-deficient mice to endotoxin. Immunity 1999; 11: 115-122.

63. Horng T, Barton GM, Medzhitov R. TIRAP: an adapter molecule in the Toll signaling pathway. Nat Immunol 2001; 2: 835-841.

64. Kyriakis JM, Avruch J. Mammalian mitogen-activated protein kinase signal transduction pathways activated by stress and inflammation. Physiol Rev 2001; 81: 807869.

65. Widmann C, Gibson S, Jarpe MB, Johnson GL. Mitogen-activated protein kinase: conservation of a three-kinase module from yeast to human. Physiol Rev 1999; 79: 143-180.

66. Carter AB, Monick MM, Hunninghake GW. Both Erk and p38 kinases are necessary for cytokine gene transcription. Am J Respir Cell Mol Biol 1999; 20: 751-758.

67. Monick MM, Carter AB, Gudmundsson G, Geist LJ, Hunninghake GW. Changes in PKC isoforms in human alveolar macrophages compared with blood monocytes. Am J Physiol 1998; 275: L389L397.

68. Monick MM, Carter AB, Gudmundsson G, Mallampalli R, Powers LS, Hunninghake GW. A phosphatidylcholine-specific phospholipase $\mathrm{C}$ regulates activation of p42/44 mitogen-activated protein kinases in lipopolysaccharide-stimulated human alveolar macrophages. J Immunol 1999; 162: 3005-3012.

69. Monick MM, Carter AB, Flaherty DM, Peterson
MW, Hunninghake GW. Protein kinase $C$ zeta plays a central role in activation of the p42/44 mitogenactivated protein kinase by endotoxin in alveolar macrophages. J Immunol 2000; 165: 4632-4639.

70. Scherle PA, Jones EA, Favata MF, et al. Inhibition of MAP kinase kinase prevents cytokine and prostaglandin E2 production in lipopolysaccharide-stimulated monocytes. J Immunol 1998; 161: 5681-5686.

71. Hambleton J, Weinstein SL, Lem L, DeFranco AL. Activation of c-Jun N-terminal kinase in bacterial lipopolysaccharide-stimulated macrophages. Proc Natl Acad Sci USA 1996; 93: 2774-2778.

72. Weinstein SL, Sanghera JS, Lemke K, DeFranco AL, Pelech SL. Bacterial lipopolysaccharide induces tyrosine phosphorylation and activation of mitogen-activated protein kinases in macrophages. $J$ Biol Chem 1992; 267 : 14955-14962.

73. Sanghera JS, Weinstein SL, Aluwalia M, Girn J, Pelech SL. Activation of multiple proline-directed kinases by bacterial lipopolysaccharide in murine macrophages. J Immunol 1996; 156: 4457-4465.

74. Swantek JL, Cobb MH, Geppert TD. Jun N-terminal kinase/stress-activated protein kinase (JNK/SAPK) is required for lipopolysaccharide stimulation of tumor necrosis factor alpha (TNF-alpha) translation: glucocorticoids inhibit TNF-alpha translation by blocking JNK/SAPK. Mol Cell Biol 1997; 17: 62746282.

75. Kyriakis JM, Brautigan DL, Ingebritsen TS, Avruch J. pp54 microtubule-associated protein-2 kinase requires both tyrosine and serine/threonine phosphorylation for activity. J Biol Chem 1991; 266: $10043-$ 10046.

76. Kyriakis JM, Avruch J. pp54 microtubule-associated protein 2 kinase. A novel serine/threonine protein kinase regulated by phosphorylation and stimulated by poly-L-lysine. J Biol Chem 1990; 265: 17355-17363.

77. Pulverer BJ, Kyriakis JM, Avruch J, Nikolakaki E, Woodgett JR. Phosphorylation of c-jun mediated by MAP kinases. Nature 1991; 353: 670-674.

78. Kallunki T, Deng T, Hibi M, Karin M. c-Jun can recruit JNK to phosphorylate dimerization partners via specific docking interactions. Cell 1996; 87: 929939.

79. Davis RJ. Signal transduction by the JNK group of MAP kinases. Cell 2000; 103: 239-252.

80. Boyle WJ, Smeal T, Defize LH, et al. Activation of protein kinase $\mathrm{C}$ decreases phosphorylation of c-Jun at sites that negatively regulate its DNA-binding activity. Cell 1991; 64: 573-584.

81. Karin M, Liu Z, Zandi E. AP-1 function and regulation. Curr Opin Cell Biol 1997; 9: 240-246.

82. Monick MM, Carter AB, Robeff PK, Flaherty DM, Peterson MW, Hunninghake GW. Lipopolysaccharide activates Akt in human alveolar macrophages resulting in nuclear accumulation and transcriptional activity of beta-catenin. J Immunol 2001; 166: 47134720.

83. Han J, Jiang Y, Li Z, Kravchenko VV, Ulevitch RJ. Activation of the transcription factor MEF2C by the MAP kinase p38 in inflammation. Nature 1997; 386 : 296-299.

84. Wilson MP, Sun Y, Cao L, Majerus PW. Inositol 1,3,4-trisphosphate 5/6-kinase is a protein kinase that phosphorylates the transcription factors c-Jun and ATF-2. J Biol Chem 2001; 276: 40998-41004.

85. Gille H, Sharrocks AD, Shaw PE. Phosphorylation of 
transcription factor p62TCF by MAP kinase stimulates ternary complex formation at c-fos promoter. Nature 1992; 358: 414 417.

86. Janknecht R, Hunter T. Convergence of MAP kinase pathways on the ternary complex factor Sap-1a. Embo $J$ 1997; 16: 1620-1627.

87. Janknecht R, Hunter T. Activation of the Sap-1a transcription factor by the c-Jun $\mathrm{N}$-terminal kinase (JNK) mitogen-activated protein kinase. $\mathrm{J}$ Biol Chem 1997; 272: 4219-4224.

88. Whitmarsh AJ, Shore P, Sharrocks AD, Davis RJ. Integration of MAP kinase signal transduction pathways at the serum response element. Science 1995; 269: 403-407.

89. Carter AB, Hunninghake GW. A constitutive active MEK - ERK pathway negatively regulates NF-kappa B-dependent gene expression by modulating TATAbinding protein phosphorylation. J Biol Chem 2000; 275: 27858-27864.

90. Young MR, Nair R, Bucheimer N, et al. Transactivation of Fra-1 and consequent activation of AP-1 occur extracellular signal-regulated kinase dependently. $\mathrm{Mol}$ Cell Biol 2002; 22: 587-598.

91. Rutault K, Hazzalin CA, Mahadevan LC. Combinations of ERK and p38 MAPK inhibitors ablate tumor necrosis factor-alpha (TNF-alpha) mRNA induction. Evidence for selective destabilization of TNF-alpha transcripts. J Biol Chem 2001; 276: 6666-6674.

92. Kontoyiannis D, Kotlyarov A, Carballo E, et al. Interleukin-10 targets p38 MAPK to modulate AREdependent TNF mRNA translation and limit intestinal pathology. Embo $J$ 2001; 20: 3760-3770.

93. Kotlyarov A, Neininger A, Schubert C, et al. MAPKAP kinase 2 is essential for LPS-induced TNF-alpha biosynthesis. Nat Cell Biol 1999; 1: 94-97.

94. Dean JL, Brook M, Clark AR, Saklatvala J. p38 mitogenactivated protein kinase regulates cyclooxygenase-2 mRNA stability and transcription in lipopolysaccharidetreated human monocytes. J Biol Chem 1999; 274 : 264-269.

95. Dumitru CD, Ceci JD, Tsatsanis C, et al. TNF-alpha induction by LPS is regulated posttranscriptionally via a Tpl2/ERK-dependent pathway. Cell 2000; 103 : 1071-1083.

96. Geppert TD, Whitehurst CE, Thompson P, Beutler B. Lipopolysaccharide signals activation of tumor necrosis factor biosynthesis through the ras/raf-1/MEK/ MAPK pathway. Mol Med 1994; 1: 93-103.

97. Buscher D, Hipskind RA, Krautwald S, Reimann T, Baccarini M. Ras-dependent and -independent pathways target the mitogen-activated protein kinase network in macrophages. Mol Cell Biol 1995; 15: 466-475.

98. Yao B, Zhang Y, Delikat S, Mathias S, Basu S, Kolesnick R. Phosphorylation of Raf by ceramideactivated protein kinase. Nature 1995; 378: 307-310.

99. Chen J, Fujii K, Zhang L, Roberts T, Fu H. Raf-1 promotes cell survival by antagonizing apoptosis signal-regulating kinase 1 through a MEK-ERK independent mechanism. Proc Natl Acad Sci USA 2001; 98: 7783-7788.

100. Hambleton J, McMahon M, DeFranco AL. Activation of Raf-1 and mitogen-activated protein kinase in murine macrophages partially mimics lipopolysaccharide-induced signaling events. J Exp Med 1995; 182: $147-154$.
101. Berridge MJ. Inositol trisphosphate and calcium signalling. Nature 1993; 361: 315-325.

102. Rhee SG, Suh PG, Ryu SH, Lee SY. Studies of inositol phospholipid-specific phospholipase C. Science 1989; 244: 546-550.

103. Monick MM, Mallampalli RK, Carter AB, et al. Ceramide regulates lipopolysaccharide-induced phosphatidylinositol 3-kinase and akt activity in human alveolar macrophages. J Immunol 2001; 167: 59775985.

104. Anderson RA, Boronenkov IV, Doughman SD, Kunz J, Loijens JC. Phosphatidylinositol phosphate kinases, a multifaceted family of signaling enzymes. $J$ Biol Chem 1999; 274: 9907-9910.

105. Peterson RT, Schreiber SL. Kinase phosphorylation: Keeping it all in the family. Curr Biol 1999; 9: R521R524.

106. Toker A. Protein kinases as mediators of phosphoinositide 3-kinase signaling. Mol Pharmacol 2000; 57: 652-658.

107. Toker A, Newton AC. Akt/protein kinase B is regulated by autophosphorylation at the hypothetical PDK-2 site. J Biol Chem 2000; 275: 8271-8274.

108. Kops GJ, Burgering BM. Forkhead transcription factors: new insights into protein kinase B (c-akt) signaling. J Mol Med 1999; 77: 656-665.

109. Cardone MH, Roy N, Stennicke HR, et al. Regulation of cell death protease caspase-9 by phosphorylation. Science 1998; 282: 1318-1321.

110. Brunet A, Bonni A, Zigmond MJ, et al. Akt promotes cell survival by phosphorylating and inhibiting a Forkhead transcription factor. Cell 1999; 96: 857868.

111. Maiti D, Bhattacharyya A, Basu J. Lipoarabinomannan from Mycobacterium tuberculosis promotes macrophage survival by phosphorylating Bad through a phosphatidylinositol 3-kinase/Akt pathway. J Biol Chem 2001; 276: 329-333.

112. Vanhaesebroeck B, Alessi DR. The PI3K-PDK1 connection: more than just a road to PKB. Biochem $J$ 2000; 346: 561-576.

113. Herrera-Velit P, Reiner NE. Bacterial lipopolysaccharide induces the association and coordinate activation of p53/56lyn and phosphatidylinositol 3-kinase in human monocytes. J Immunol 1996; 156: $1157-$ 1165.

114. Herrera-Velit P, Knutson KL, Reiner NE. Phosphatidylinositol 3-kinase-dependent activation of protein kinase C-zeta in bacterial lipopolysaccharide-treated human monocytes. J Biol Chem 1997; 272: 1644516452.

115. Arbibe L, Mira J, Teusch N, et al. Toll-like receptor 2-mediated NF-kB activation requires a Rac1dependent pathway. Nature 2000; 1: 533-540.

116. Mathias S, Pena LA, Kolesnick RN. Signal transduction of stress via ceramide. Biochem J 1998; 335: 465480.

117. Prieschl EE, Baumruker T. Sphingolipids: second messengers, mediators and raft constituents in signaling. Immunol Today 2000; 21: 555-560.

118. Hannun YA, Luberto C. Ceramide in the eukaryotic stress response. Trends Cell Biol 2000; 10: 73-80.

119. Kolesnick RN, Kronke M. Regulation of ceramide production and apoptosis. Annu Rev Physiol 1998; 60: 643-665.

120. Mathias S, Dressler KA, Kolesnick RN. Characterization of a ceramide-activated protein kinase: 
stimulation by tumor necrosis factor alpha. Proc Natl Acad Sci USA 1991; 88: 10009-10013.

121. Huwiler A, Brunner J, Hummel R, et al. Ceramidebinding and activation defines protein kinase c-Raf as a ceramide-activated protein kinase. Proc Natl Acad Sci USA 1996; 93: 6959-6963.

122. Hannun YA, Loomis CR, Merrill AH Jr, Bell RM. Sphingosine inhibition of protein kinase $\mathrm{C}$ activity and of phorbol dibutyrate binding in vitro and in human platelets. J Biol Chem 1986; 61: 12604-12609.

123. Hisano N, Yatomi Y, Fujino MA, Igarashi Y, Kume S, Ozaki Y. Quantification of sphingosine derivatives in human platelets: inducible formation of free sphingosine. J Biochem (Tokyo) 1998; 123: 263-268.

124. Sweeney EA, Inokuchi J, Igarashi Y. Inhibition of sphingolipid induced apoptosis by caspase inhibitors indicates that sphingosine acts in an earlier part of the apoptotic pathway than ceramide. FEBS Lett 1998; 425: $61-65$

125. Sakakura C, Sweeney EA, Shirahama T, et al. Selectivity of sphingosine-induced apoptosis. Lack of activity of DL-erythyro-dihydrosphingosine. Biochem Biophys Res Commun 1998; 246: 827-830.

126. Lee MJ, Van Brocklyn JR, Thangada S, et al. Sphingosine-1-phosphate as a ligand for the $\mathrm{G}$ protein-coupled receptor EDG-1. Science 1998; 279: 1552-1555.

127. Zondag GC, Postma FR, Etten IV, Verlaan I, Moolenaar WH. Sphingosine 1-phosphate signalling through the G-protein-coupled receptor Edg-1. Biochem J 1998; 330: 605-609.

128. Goetzl EJ, Kong Y, Mei B. Lysophosphatidic acid and sphingosine 1-phosphate protection of $\mathrm{T}$ cells from apoptosis in association with suppression of Bax. J Immunol 1999; 162: 2049-2056.

129. Procyk KJ, Kovarik P, von Gabain A, Baccarini M. Salmonella typhimurium and lipopolysaccharide stimulate extracellularly regulated kinase activation in macrophages by a mechanism involving phosphatidylinositol 3-kinase and phospholipase D as novel intermediates. Infect Immun 1999; 67: 1011-1017.

130. Medvedev AE, Blanco JC, Qureshi N, Vogel SN. Limited role of ceramide in lipopolysaccharidemediated mitogen-activated protein kinase activation, transcription factor induction, and cytokine release. J Biol Chem 1999; 274: 9342-9350.

131. MacKichan ML, DeFranco AL. Role of ceramide in lipopolysaccharide (LPS)-induced signaling. LPS increases ceramide rather than acting as a structural homolog. J Biol Chem 1999; 274: 1767-1775.

132. Blackwell TS, Christman JW. The role of nuclear factor-kappa B in cytokine gene regulation. $A m$ J Respir Cell Mol Biol 1997; 17: 3-9.

133. Muller JM, Ziegler-Heitbrock HW, Baeuerle PA. Nuclear factor kappa B, a mediator of lipopolysaccharide effects. Immunobiology 1993; 187: 233-256.

134. Silverman N, Maniatis T. NF-kappaB signaling pathways in mammalian and insect innate immunity. Genes Dev 2001; 15: 2321-2342.

135. Karin M. The beginning of the end: IkappaB kinase (IKK) and NF-kappaB activation. J Biol Chem 1999; 274: 27339-27342.

136. May MJ, Ghosh S. IkappaB kinases: kinsmen with different crafts. Science 1999; 284: 271-273.

137. Karin M, Ben-Neriah Y. Phosphorylation meets ubiquitination: the control of NF-[kappa]B activity. Annu Rev Immunol 2000; 18: 621-663.

138. Zandi E, Chen Y, Karin M. Direct phosphorylation of
IkappaB by IKKalpha and IKKbeta: discrimination between free and NF-kappaB-bound substrate. Science 1998; 281: 1360-1363.

139. Hawiger J, Veach RA, Liu XY, Timmons S, Ballard DW. IkappaB kinase complex is an intracellular target for endotoxic lipopolysaccharide in human monocytic cells. Blood 1999; 94: 1711-1716.

140. O'Connell MA, Bennett BL, Mercurio F, Manning AM, Mackman N. Role of IKK1 and IKK2 in lipopolysaccharide signaling in human monocytic cells. J Biol Chem 1998; 273: 30410-30414.

141. Swantek JL, Tsen MF, Cobb MH, Thomas JA. IL-1 receptor-associated kinase modulates host responsiveness to endotoxin. J Immunol 2000; 164: 4301-4306.

142. Nakano H, Shindo M, Sakon S, et al. Differential regulation of IkappaB kinase alpha and beta by two upstream kinases, NF-kappaB-inducing kinase and mitogen-activated protein kinase/ERK kinase kinase1. Proc Natl Acad Sci USA 1998; 95: 3537-3542.

143. Wang C, Deng L, Hong M, Akkaraju GR, Inoue J, Chen ZJ. TAK1 is a ubiquitin-dependent kinase of MKK and IKK. Nature 2001; 412: 346-351.

144. Ozes ON, Mayo LD, Gustin JA, Pfeffer SR, Pfeffer LM, Donner DB. NF-kappaB activation by tumour necrosis factor requires the Akt serine-threonine kinase. Nature 1999; 401: 82-85.

145. Luftig MA, Cahir-McFarland E, Mosialos G, Kieff E. Effects of the NIK aly mutation on NF-kappaB activation by the Epstein-Barr virus latent infection membrane protein, lymphotoxin beta receptor, and CD40. J Biol Chem 2001; 276: 14602-14606.

146. Kopp E, Medzhitov R, Carothers J, et al. ECSIT is an evolutionarily conserved intermediate in the Toll/ IL-1 signal transduction pathway. Genes Dev 1999; 13 : 2059-2071.

147. Takaesu G, Kishida S, Hiyama A, et al. TAB2, a novel adaptor protein, mediates activation of TAK1 MAPKKK by linking TAK1 to TRAF6 in the IL-1 signal transduction pathway. Mol Cell 2000; 5: 649658.

148. Cobb RR, Felts KA, Parry GC, Mackman N. D609, a phosphatidylcholine-specific phospholipase $\mathrm{C}$ inhibitor, blocks interleukin-1 beta-induced vascular cell adhesion molecule 1 gene expression in human endothelial cells. Mol Pharmacol 1996; 49: 998-1004.

149. Yoza BK, Hu JY, McCall CE. Protein-tyrosine kinase activation is required for lipopolysaccharide induction of interleukin 1beta and NFkappaB activation, but not NFkappaB nuclear translocation. $J$ Biol Chem 1996; 271: 18306-18309.

150. Zhong H, Voll RE, Ghosh S. Phosphorylation of NF-kappa B p65 by PKA stimulates transcriptional activity by promoting a novel bivalent interaction with the coactivator CBP/p300. Mol Cell 1998; 1: 661-671.

151. Zhong H, SuYang H, Erdjument-Bromage H, Tempst $\mathrm{P}$, Ghosh S. The transcriptional activity of NFkappaB is regulated by the IkappaB-associated PKAc subunit through a cyclic AMP-independent mechanism. Cell 1997; 89: 413-424.

152. Anrather J, Csizmadia V, Soares MP, Winkler H. Regulation of NF-kappaB RelA phosphorylation and transcriptional activity by $\mathrm{p} 21$ (ras) and protein kinase Czeta in primary endothelial cells. J Biol Chem 1999; 274: 13594-13603.

153. Madrid LV, Mayo MW, Reuther JY, Baldwin AS Jr. Akt stimulates the transactivation potential of the RelA/p65 Subunit of NF-kappa B through utilization 
of the Ikappa B kinase and activation of the mitogenactivated protein kinase p38. J Biol Chem 2001; 276: 18934-18940.

154. Matthews JR, Wakasugi N, Virelizier JL, Yodoi J, Hay RT. Thioredoxin regulates the DNA binding activity of NF-kappa B by reduction of a disulphide bond involving cysteine 62. Nucleic Acids Res 1992; 20: 3821-3830.

155. Hirota K, Matsui M, Murata M, et al. Nucleoredoxin, glutaredoxin, and thioredoxin differentially regulate NF-kappaB, AP-1, and CREB activation in HEK293 cells. Biochem Biophys Res Commun 2000; 274: 177182.

156. Monick MM, Carter AB, Hunninghake GW. Human alveolar macrophages are markedly deficient in REF-1 and AP-1 DNA binding activity. J Biol Chem 1999; 274: $18075-18080$

157. Flaherty DM, Monick MM, Carter AB, Peterson
MW, Hunninghake GW. GM-CSF increases AP-1 DNA binding and Ref-1 amounts in human alveolar macrophages. Am J Respir Cell Mol Biol 2001; 25: 254-259.

158. Kerr LD, Ransone LJ, Wamsley P, et al. Association between proto-oncoprotein Rel and TATA-binding protein mediates transcriptional activation by NFkappa B. Nature 1993; 365: 412-419.

159. Xu X, Prorock C, Ishikawa H, Maldonado E, Ito Y, Gelinas C. Functional interaction of the v-Rel and c-Rel oncoproteins with the TATA-binding protein and association with transcription factor IIB. Mol Cell Biol 1993; 13: 6733-6741.

160. Caivano M, Gorgoni B, Cohen P, Poli V. The induction of cyclooxygenase- 2 mRNA in macrophages is biphasic and requires both $\mathrm{C} / \mathrm{EBP} \beta$ and C/EBP $\delta$ transcription factors. $J$ Biol Chem 2001; 276: 48693-48701. 